\title{
Standardizing and Setting Standard Levels for Physical of Skill-Based Tests for Measuring the Speed and Accuracy Some Types of Response Skill for fleuret players \\ ${ }^{1}$ Dr/ Rasha Rabae Fahmy Ali Al-dien
}

Introduction and research problem

Test and measurement are of the most important evaluation tools that give trainers a clear vision of their players' and teams' level, the effectiveness of the training programs, the specification of players' training level and how developed the sportive achievement level. This can be achieved through putting standard levels for tests, This is done by setting standard levels of tests, thus clarifying the role and importance of theoretical (applied) scientific research in the codification of tests and measurements used in the training process and the competitive evaluation and evaluation of performance development.

Both Ibrahim Nabil (2001), Hussein Haggag and Ramzy Altanbouly (2007) indicated that fencing is one of speed sports since a slow player is unable to compete. Speed, too, has a great impact on players' scores. The ultimate goal of performing movements is the accurate recording of touches on the correct goal of the rival $(1: 31$ 38) (5:77).
Mentionsed, Abdurrahman (2006) and Osama Abdurrahman et al (2009) said that the response movement is one of the most important components of fencing and that the player has to master its different performance ways so that they shall not miss the opportunities of recording their touches. Response movement must thus be performed at the highest speed and accuracy possible after each successful defense against the disengage's hits. This means the necessity of linking response to defensethis is what the referee confirms as there is no analysis of individual response in matches but it is always liked to defense as it includes both the analysis of response and defense together (2:253-255) (3:96).

By the previous illustration of the significance of response skill's accuracy and speed, the researcher's review of some references and referential surveying of some research and to the best of her knowledge, the researcher found that there are no standardized tests imitating the

${ }^{1}$ A lecturer of sportive training in the training department and movement science at the Faculty of Physical Education, Assiut University Egypt.

Assiut Journal For Sport Science Arts 
competitive atmosphere and the competitors' interaction when performing response skill corresponding the competition of a positive strong disengage in tests to the extent that the examinee has to successfully defend then to respond. Some tests were used as tools to fasten a sword on wall so that the player hits on the fastened sword and record the touch on the wall for measuring the speed and accuracy of response skill. Such tests are lacking the attack since the fastened sword means there is no defense. Thus, such tests do not measure response skill since there is no interaction among examinees as in actual competition and training. Among these studies are that of Mohamed Mahmoud (2014) (11).

Some studies used traditional tests depending on self-report which is not an objective mean that is affected by the expert's mood or bias in favor of some examinees during assessment, according to Mohamed Sobhy (1995) and Liyla Alsayed (2005) (8:171) (7:74) referred to.

Through the researcher's experience as a previous trainer in the fencing generations project and a trainer of Assiut University's fencing team and through watching some regional and international competitions in Cairo Stadium of fleuret players under 20 years, she analyzed some matches( 7matches)(appendix 1), to identify the most common types of response skill used with accuracy and speed and identify which parts lead to a rival's goal. Through calculating each type's percentage of frequencie, the researcher found that the mot used skill is simple response (by the coupdroit and disengage) and the complex (by the nu deux) in the sixth, fourth, seventh and eighth fencing swords and players under 20 years. as table (1) illustrates

\section{Table (1)}

\begin{tabular}{|c|c|c|c|c|c|}
\hline response by the & coupdroit & disengage & \multicolumn{2}{|c|}{ nu deux } & \multirow{2}{*}{$\% 1 \ldots$} \\
\hline percentiles & $\% \circ r . \leqslant \Lambda$ & $\% r \cdot . r \leq$ & \multicolumn{2}{|c|}{$\% 17 . \mathrm{r}$} & \\
\hline fencing swords & $\begin{array}{l}\text { the } \\
\text { fourth }\end{array}$ & the sixth & $\begin{array}{c}\text { the } \\
\text { seventh }\end{array}$ & $\begin{array}{l}\text { the } \\
\text { eighth }\end{array}$ & \multirow[t]{2}{*}{$\% 1 \ldots$} \\
\hline percentiles & $\%$ Y०.01 & $\% \leq 7.01$ & $\% 11.74$ & $\%)\rceil . \nvdash \wedge$ & \\
\hline
\end{tabular}

Thus, the researcher tries to standardize 12 physical skillbased tests characterized by objectivity to be applied in fencing and to set standard levels whereby we can identify the level of development of players' performance compared to their counterparts or their performance through the 
training program and competition, and to ensure if there is a correlation between performance speed and accuracy-so that we can provide those of interest and trainers with a standardized tool for measuring the speed and accuracy

of some types of response in fencing for under-20-year players.

\section{The two Research Objectives}

This research aims to standardize and set standard levels for physical skill-based tests through measuring the speed and accuracy of some types of response skill of the sixth, seventh and eighth fleuret players under 20 years and identify the correlation between performance speed and accuracy during the test under investigation.

\section{Research Questions}

1- What are the skills that measure the speed and accuracy of simple response skill (by the coupdroit and disengage) and the complex (by the numerical) of the sixth, fourth, seventh and eighth fleuret players under 20 years?

2- Is it possible to set standard levels suitable for the tests measuring the speed and accuracy of simple response skill (by the coupdroit and disengage) and the complex (by the numerical) of the sixth, fourth, seventh and eighth fleuret players under 20 years?

3- Is there a correlation between speed and accuracy of simple response skill (by the coupdroit and disengage ) and the complex (by the numerical) of the sixth, fourth, seventh and eighth fleuret players under 20 years?

\section{Research terminology}

Test: It is the response of an individual in a situation including intentionally organized stimuli with specific characteristics for the individual in a special way that allows the researcher to record and measure such responses accurately. (13) (14)

Response: It is the attack following a successful defense. (2: 253)

The speed: is the ability to perform certain movements in the shortest possible time. (15) Precision: is the ability to direct the voluntary movements of the individual towards a particular goal. (16)

\section{Research methodology}

Research method: the current study used descriptive research method for its equivalence for the current research nature.

Population: The population included fencing under(20)year players registered in the Egyptian fencing union.

\section{Sample:}

The sample included (44) fleuret players (14) players in 6 October Club, (16) players in Maadi Club, (14) and Shooting 
Club. The sample was purposefully chosen from the three clubs; the first and second pilot studies were administered upon (12) years who were excluded as well as (6) absent players. The sample then consisted of (26) players including the strong positive disengage so the tests were administered upon (25) players only. The researcher equated the sample as table (r) illustrates:

\section{Table ( $r$ )}

Statistical Description of growth variables and physical skill-based variables of the sample $(\mathrm{N}=25)$

\begin{tabular}{|c|c|c|c|c|c|c|}
\hline Z & $\begin{array}{l}\text { Statistical } \\
\text { Coefficients } \\
\text { variables }\end{array}$ & 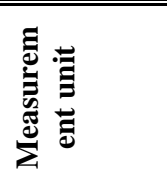 & 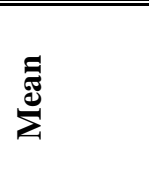 & 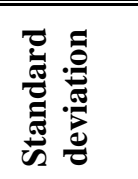 & 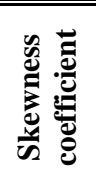 & 量 \\
\hline 1 & Age & Year & 19.0500 & .75859 & -.184 & -1.092 \\
\hline 2 & Length & Centimeter & 177.5000 & 3.77793 & -1.062 & .386 \\
\hline 3 & Weight & Kilogram & 70.5000 & 4.14510 & -.078 & -1.838 \\
\hline 4 & Training age & Year & 7.5833 & 1.16450 & -.241 & -1.352 \\
\hline \multirow[t]{2}{*}{5} & \multirow{2}{*}{$\begin{array}{l}\text { Test of speed and accuracy } \\
\text { of response by the coupdroit } \\
\text { in the sixth }\end{array}$} & Second & .5883 & .03635 & -.153 & -.649 \\
\hline & & Score & 8.0833 & 1.31137 & .110 & -1.185 \\
\hline \multirow[t]{2}{*}{6} & \multirow{2}{*}{$\begin{array}{l}\text { Test of speed and accuracy } \\
\text { of response by the } \\
\text { disengage in the sixth }\end{array}$} & Second & 1.1066 & .06108 & 1.113 & .744 \\
\hline & & Score & 6.6667 & 1.37069 & -.292 & .203 \\
\hline \multirow[t]{2}{*}{7} & \multirow{2}{*}{$\begin{array}{l}\text { Test of speed and accuracy } \\
\text { of response by the nu deux } \\
\text { in the sixth }\end{array}$} & Second & 1.3018 & .03605 & .256 & -.713 \\
\hline & & Score & 6.7500 & 1.21543 & .205 & -.406 \\
\hline \multirow[t]{2}{*}{8} & \multirow{2}{*}{$\begin{array}{l}\text { Test of speed and accuracy } \\
\text { of response by the coupdroit } \\
\text { in the fourth }\end{array}$} & Second & .6938 & .01443 & -.748 & -.329 \\
\hline & & Score & 7.0833 & 1.08362 & -.192 & .219 \\
\hline \multirow[t]{2}{*}{9} & \multirow{2}{*}{$\begin{array}{l}\text { Test of speed and } \\
\text { accuracy of response by } \\
\text { the disengage in the } \\
\text { fourth }\end{array}$} & Second & 1.2098 & .03517 & .552 & -1.278 \\
\hline & & Score & 6.9167 & 1.31137 & -.690 & 1.159 \\
\hline \multirow[t]{2}{*}{10} & \multirow{2}{*}{$\begin{array}{l}\text { Test of speed and } \\
\text { accuracy of response by } \\
\text { the nu deux in the fourth }\end{array}$} & Second & 1.2098 & .03517 & .552 & -1.278 \\
\hline & & Score & 6.9167 & 1.31137 & -.690 & 1.159 \\
\hline \multirow[t]{2}{*}{11} & \multirow{2}{*}{$\begin{array}{l}\text { Test of speed and accuracy } \\
\text { of response by the coupdroit } \\
\text { in the seventh }\end{array}$} & Second & .6958 & .00710 & .362 & -1.432 \\
\hline & & Score & 6.4167 & 1.67649 & -.105 & -1.242 \\
\hline
\end{tabular}


Follow Table ( $r$ )

Statistical Description of growth variables and physical skill-based variables of the sample $(\mathrm{N}=25)$

\begin{tabular}{|c|c|c|c|c|c|c|}
\hline$\stackrel{\ominus}{Z}$ & $\begin{array}{l}\text { Statistical } \\
\text { Coefficients } \\
\text { variables }\end{array}$ & 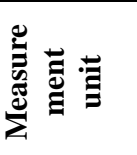 & $\sum_{\Sigma}^{\Xi}$ & 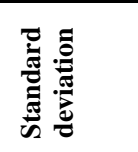 & 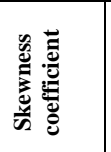 & 量 \\
\hline \multirow[t]{2}{*}{12} & \multirow{2}{*}{$\begin{array}{l}\text { Test of speed and accuracy } \\
\text { of response by the } \\
\text { disengage in the seventh }\end{array}$} & Second & 1.2161 & .09348 & 1.965 & 1.453 \\
\hline & & Score & 7.0000 & 1.59545 & -.322 & -.434 \\
\hline \multirow[t]{2}{*}{13} & \multirow{2}{*}{$\begin{array}{l}\text { Test of speed and accuracy } \\
\text { of response by the nu deux } \\
\text { in the seventh }\end{array}$} & Second & 1.3526 & .03537 & -.715 & -1.031 \\
\hline & & Score & 7.0833 & 1.16450 & -.189 & -.667 \\
\hline \multirow[t]{2}{*}{14} & \multirow{2}{*}{$\begin{array}{l}\text { Test of speed and accuracy } \\
\text { of response by the coupdroit } \\
\text { in the eighth }\end{array}$} & Second & .6042 & .05725 & -.036 & -.081 \\
\hline & & Score & 6.6667 & 1.49747 & -.289 & -.726 \\
\hline \multirow[t]{2}{*}{15} & \multirow{2}{*}{$\begin{array}{l}\text { Test of speed and accuracy } \\
\text { of response by the } \\
\text { disengage in the eighth }\end{array}$} & Second & 1.1620 & .05427 & -.839 & -.898 \\
\hline & & Score & 6.1667 & 1.74946 & -.181 & -.428 \\
\hline \multirow[t]{2}{*}{16} & \multirow{2}{*}{$\begin{array}{l}\text { Test of speed and } \\
\text { accuracy of response by } \\
\text { the nu deux in the eighth }\end{array}$} & Second & 1.3134 & .03573 & 1.330 & 1.439 \\
\hline & & Score & 7.3333 & 1.23091 & -.416 & -.449 \\
\hline \multicolumn{3}{|c|}{ Sample selection conditions: } & \multicolumn{4}{|c|}{ devices to measure the research } \\
\hline \multicolumn{3}{|c|}{ - the sample's individuals } & \multicolumn{4}{|c|}{ variables: } \\
\hline \multirow{2}{*}{\multicolumn{3}{|c|}{$\begin{array}{l}\text { must not be less than }(\mathrm{IV}) \\
\text { years old and not more than } \\
(Y \cdot) \text {, }\end{array}$}} & \multirow{5}{*}{\multicolumn{4}{|c|}{$\begin{array}{l}\text { - a medical scales for } \\
\text { measuring weight, to the } \\
\text { approximate kilogram, to } \\
\text { which is a restameter is } \\
\text { attached to measure height to } \\
\text { the approximate centimeter, }\end{array}$}} \\
\hline & & & & & & \\
\hline & all the sam & & & & & \\
\hline \multicolumn{3}{|c|}{ individuals are registered in the } & & & & \\
\hline \multicolumn{3}{|c|}{ Egyptian fencing union, } & & & & \\
\hline \multicolumn{3}{|c|}{$\begin{array}{l}\text { there is a prominent } \\
\text { player ranked fourth in the } \\
\text { national competition from the } 6\end{array}$} & \multicolumn{4}{|c|}{$\begin{array}{l}\text { sample's individuals' heights in } \\
\text { growth and physical skill-based }\end{array}$} \\
\hline \multicolumn{3}{|c|}{ October Club who acts as a } & \multicolumn{4}{|c|}{ tests (appendix 2, 3) } \\
\hline \multicolumn{3}{|c|}{ strong positive disengage } & \multicolumn{4}{|c|}{ - a laptop with media } \\
\hline \multicolumn{3}{|c|}{ during the test to encourage the } & \multicolumn{4}{|c|}{ player classic installed for } \\
\hline \multicolumn{3}{|c|}{ competitive atmosphere) who } & & \multicolumn{2}{|c|}{ measuring speed $1 / 1000 \mathrm{~s}$, } & \\
\hline \multicolumn{3}{|c|}{$\begin{array}{l}\text { is willing to move to other } \\
\text { clubs. } \\
\text { Data collection instruments } \\
\text { used in the research: }\end{array}$} & \multicolumn{4}{|c|}{$\begin{array}{l}\text { swordsman's suit - a camera } \\
\text { with } 1 / 1000 \mathrm{~s} \text { speed and its } \\
\text { stick, and }\end{array}$} \\
\hline \multicolumn{3}{|c|}{$\begin{array}{l}\text { used in the research: } \\
\text { The researcher used the } \\
\text { following instruments and }\end{array}$} & \multicolumn{4}{|c|}{$\begin{array}{l}\text { 2- fencing swords and a whistle } \\
\text { for signaling the starting point. } \\
\text { Steps of constructing the test: }\end{array}$} \\
\hline
\end{tabular}


The majority of resources related to measurement and evaluation agree on the following steps when constructing the test:

1- specifying the phenomenon to be measured,

2- specifying the test purpose,

3- specifying the phenomenon and developing specification tables,

4- $\quad$ specifying test units and its final format,

5- setting the test conditions and administration instructions,

6- calculating statistical coefficients of the test, and

7- administering the test and setting standards.

The first pilot study:

This study was administered on Saturday the $2^{\text {nd }}$ April, 2016 to Friday the $8^{\text {th }}$, April, 2016 including a sample of 12 players divided among the three clubs, 3 for each club, out of the main research sample in order to identify the obstacles and difficulties that may face the researcher in the second pilot study and controlling the distances in order to identify where to fasten the camera stick in the players' training halls at each club, to ensure the tools validity and to train the assistants (appendix 6).

The second pilot study:

This study was administered on Saturday the $9^{\text {th }}$, April, 2016 to Friday the $15^{\text {th }}$, April, 2016 to identify the statistical coefficients (validity and reliability) to administer the tests under study.

Validity

coefficient (discrimination validity):

The researcher administered the tests on a discriminative sample consisting of 12 under20 -year fleuret players and a non-discriminative sample of 12 players specialized in "training on fencing" in the third year (20 years) out of the main sample in order to calculate the discrimination validity of the used tests, as table rillustrates:

\section{Table $(r)$}

The mean, total grades and $Z$ value (Man Whitney test) of the significance of differences of the two discriminative and nondiscriminative groups in the tests under study

\begin{tabular}{|c|c|c|c|c|c|c|c|}
\hline \multirow{2}{*}{ Z } & \multirow{2}{*}{ Variables } & \multirow{2}{*}{ 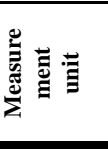 } & \multicolumn{2}{|c|}{$\begin{array}{c}\text { Discriminative } \\
\text { group }\end{array}$} & \multicolumn{2}{|c|}{$\begin{array}{c}\text { Non-discriminative } \\
\text { group }\end{array}$} & \multirow{2}{*}{ 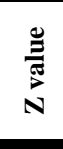 } \\
\hline & & & $\begin{array}{l}\text { Mean } \\
\text { of the } \\
\text { grades }\end{array}$ & $\begin{array}{c}\text { Total } \\
\text { grades }\end{array}$ & $\begin{array}{l}\text { Mean } \\
\text { of the } \\
\text { grades }\end{array}$ & $\begin{array}{r}\text { Total } \\
\text { grades }\end{array}$ & \\
\hline \multirow[t]{2}{*}{1} & \multirow{2}{*}{$\begin{array}{l}\text { Test of speed and accuracy of } \\
\text { response by the coupdroit in } \\
\text { the sixth }\end{array}$} & Second & T. & $11 r$ & $9 . \wedge 1$ & 111.07 & r. $10_{-}$ \\
\hline & & Score & A.VI & $1 \cdot \leq .0$ & $\vee .10$ & $9 \leq . r$ & r.00_ \\
\hline \multirow[t]{2}{*}{2} & \multirow{2}{*}{$\begin{array}{l}\text { Test of speed and accuracy of } \\
\text { response by the disengage in } \\
\text { the sixth }\end{array}$} & Second & $9.7 V$ & 117 & 9.99 & 119.11 & r.70_ \\
\hline & & Score & 9.19 & $11 V .0$ & $9.4 T$ & $11 \cdot .17$ & r.TY \\
\hline
\end{tabular}


Follow Table ( $\left.{ }^{\mu}\right)$

The mean, total grades and $Z$ value (Man Whitney test) of the significance of differences of the two discriminative and nondiscriminative groups in the tests under study

\begin{tabular}{|c|c|c|c|c|c|c|c|}
\hline \multirow{2}{*}{ Z } & \multirow{2}{*}{ Variables } & \multirow{2}{*}{ 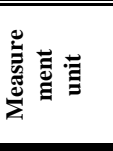 } & \multicolumn{2}{|c|}{$\begin{array}{c}\text { Discriminative } \\
\text { group }\end{array}$} & \multicolumn{2}{|c|}{$\begin{array}{c}\text { Non-discriminative } \\
\text { group }\end{array}$} & \multirow{2}{*}{ 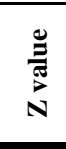 } \\
\hline & & & $\begin{array}{l}\text { Mean } \\
\text { of the } \\
\text { grades }\end{array}$ & $\begin{array}{c}\text { Total } \\
\text { grades }\end{array}$ & $\begin{array}{l}\text { Mean } \\
\text { of the } \\
\text { grades }\end{array}$ & $\begin{array}{r}\text { Total } \\
\text { grades }\end{array}$ & \\
\hline \multirow[t]{2}{*}{3} & \multirow{2}{*}{$\begin{array}{l}\text { Test of speed and accuracy of } \\
\text { response by the nu deux in the } \\
\text { sixth }\end{array}$} & Second & $9.7 V$ & 117 & 9.19 & 111.71 & r.90. \\
\hline & & Score & $1.9 Y$ & $1 . V$ & N. Yo & 99 & r.91- \\
\hline \multirow[t]{2}{*}{4} & \multirow{2}{*}{$\begin{array}{l}\text { Test of speed and accuracy of } \\
\text { response by the coupdroit in } \\
\text { the fourth }\end{array}$} & Second & $9 . \leqslant 7$ & 111.0 & $9 . \wedge 7$ & IIN.r & $r . \leqslant 0_{-}$ \\
\hline & & Score & $9.7 V$ & 117 & 9 & $1 \cdot 1$ & r.r. \\
\hline \multirow[t]{2}{*}{5} & \multirow{2}{*}{$\begin{array}{l}\text { Test of speed and accuracy of } \\
\text { response by the disengage in } \\
\text { the fourth }\end{array}$} & Second & 9 & $1 \cdot 1$ & 1. & ir. & r.r. \\
\hline & & Score & $1.9 Y$ & $1 . v$ & $\Lambda$ & 97 & Y.TV- \\
\hline \multirow[t]{2}{*}{6} & \multirow{2}{*}{$\begin{array}{l}\text { Test of speed and accuracy of } \\
\text { response by the nu deux in the } \\
\text { fourth }\end{array}$} & Second & 1. IV & 91 & 9.17 & $11 \cdot . \varepsilon$ & r.^9. \\
\hline & & Score & 1. ro & 99 & V.ro & AV & r.99. \\
\hline \multirow[t]{2}{*}{7} & \multirow{2}{*}{$\begin{array}{l}\text { Test of speed and accuracy of } \\
\text { response by the coupdroit in } \\
\text { the seventh }\end{array}$} & Second & 9.0 & $11 \leq$ & $9 . \vee \wedge$ & IV.r. & r.r. \\
\hline & & Score & A. IV & $9 \wedge$ & $\wedge$ & 97 & r.^9. \\
\hline \multirow[t]{2}{*}{8} & \multirow{2}{*}{$\begin{array}{l}\text { Test of speed and accuracy of } \\
\text { response by the disengage in } \\
\text { the seventh }\end{array}$} & Second & 9.10 & 111 & 9.19 & 111.71 & r.ON- \\
\hline & & Score & 1. $\vee 9$ & 1.0 .0 & A.Y & 99.14 & r.79. \\
\hline \multirow[t]{2}{*}{9} & \multirow{2}{*}{$\begin{array}{l}\text { Test of speed and accuracy of } \\
\text { response by the nu deux in the } \\
\text { seventh }\end{array}$} & Second & N.r & $1 \ldots$ & 1.9r & 1.8 .17 & 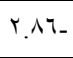 \\
\hline & & Score & ᄉ.ґ人 & $1 \cdots 0$ & V.AT & QE.rT & r.AT_ \\
\hline \multirow[t]{2}{*}{10} & \multirow{2}{*}{$\begin{array}{l}\text { Test of speed and accuracy of } \\
\text { response by the coupdroit in } \\
\text { the eighth }\end{array}$} & Second & 9.10 & $11 \mathrm{~V}$ & 9.91 & 119.17 & Y. \\
\hline & & Score & $9.1 \mathrm{~V}$ & 11. & A.IV & $91 . \cdot \leq$ & Y.O \\
\hline \multirow[t]{2}{*}{11} & \multirow{2}{*}{$\begin{array}{l}\text { Test of speed and accuracy of } \\
\text { response by the disengage in } \\
\text { the eighth }\end{array}$} & Second & 9.45 & 114 & $9 . \wedge 7$ & $111 . r \mathrm{r}$ & r. $\leqslant 0_{-}$ \\
\hline & & Score & $1 . .1 r$ & $|r| .0$ & 9.0 & $11 \leq$ & Y.VA- \\
\hline \multirow[t]{2}{*}{12} & \multirow{2}{*}{$\begin{array}{l}\text { Test of speed and accuracy of } \\
\text { response by the nu deux in the } \\
\text { eighth }\end{array}$} & Second & 9.5 & 1.1 .0 & 9.91 & 119.87 & Y.V $V_{-}$ \\
\hline & & Score & $9.0 \leqslant$ & $11 \leq .0$ & 1.07 & I.Y.VY & Y.7T. \\
\hline
\end{tabular}

\section{$\mathrm{Z}$ value at 0.05 level of significance $=1.96$}

Through the table, it is clear thus indicating that the that there are statistically significant differences between the mean scores of the two measurements of the two discriminative and nondiscriminative groups on the tests, favoring the mean of the discriminative group's grades, physical skill-based tests under study discriminate among the players, thus indicating the discriminative validity of the tests under study.

\section{Reliability coefficient:}

For validation purposes, the researcher administered and re- 
administered the test on the same sample after 7 days of the first administration under the same testing conditions to ensure the test is reliable and ensure the scientific bases of tests, as table ( $₹$ ) illustrates:

Table ( $\varepsilon$ )

Reliability coefficient of the tests under study $(\mathrm{N}=12)$

\begin{tabular}{|c|c|c|c|c|c|c|c|}
\hline \multirow{2}{*}{$\stackrel{0}{Z}$} & \multirow[b]{2}{*}{ Variables } & \multirow{2}{*}{ 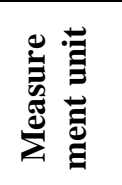 } & \multicolumn{2}{|c|}{$\begin{array}{c}\text { First } \\
\text { administration }\end{array}$} & \multicolumn{2}{|c|}{$\begin{array}{c}\text { Second } \\
\text { administration }\end{array}$} & \multirow{2}{*}{ 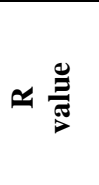 } \\
\hline & & & స్త & 预 & $\stackrel{\Xi}{\tilde{E}}$ & 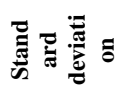 & \\
\hline \multirow[t]{2}{*}{1} & \multirow{2}{*}{$\begin{array}{c}\text { Test of speed and accuracy } \\
\text { of response by the } \\
\text { coupdroit in the sixth }\end{array}$} & Second & .09 & $\because \varepsilon$ & .00 & $\because v$ & $\cdot \wedge \leq 0$ \\
\hline & & Score & A. $7 \mathrm{~V}$ & 1.1 & 1.0 &.$\wedge \varepsilon$ & $.91 Y$ \\
\hline \multirow[t]{2}{*}{2} & \multirow{2}{*}{$\begin{array}{c}\text { Test of speed and accuracy } \\
\text { of response by the } \\
\text { disengage in the sixth }\end{array}$} & Second & 1.1 & $\because v$ & 1.9 & $\because \lambda$ & .919 \\
\hline & & Score & 7.0 & 1.0 & אוT & 1.41 & .94 \\
\hline \multirow[t]{2}{*}{3} & \multirow{2}{*}{$\begin{array}{l}\text { Test of speed and } \\
\text { accuracy of response by } \\
\text { the nu deux in the sixth }\end{array}$} & Second & r. & $\because 0$ & 1.49 & $\because \cdot \varepsilon$ & $\cdot 107$ \\
\hline & & Score & $V .1 \mathrm{~V}$ & $1 . \leqslant V$ & $v . \wedge$ & 1.07 & .994 \\
\hline \multirow[t]{2}{*}{4} & \multirow{2}{*}{$\begin{array}{c}\text { Test of speed and accuracy } \\
\text { of response by the } \\
\text { coupdroit in the fourth }\end{array}$} & Second & .79 & $\because r$ & $\because V$ & $\because r$ & .941 \\
\hline & & Score & V & $\because \wedge 9$ & 7.人 & $.1 \mathrm{VO}$ & $\because \wedge 91$ \\
\hline \multirow[t]{2}{*}{5} & \multirow{2}{*}{$\begin{array}{c}\text { Test of speed and accuracy } \\
\text { of response by the } \\
\text { disengage in the fourth }\end{array}$} & Second & سז.1. & $\because 0$ & $1 . r \varepsilon$ & $\because v$ &.$\wedge r$ \\
\hline & & Score & V.ru &.$O r$ & V.YO & .71 & $\cdot 9 \leq 9$ \\
\hline \multirow[t]{2}{*}{6} & \multirow{2}{*}{$\begin{array}{l}\text { Test of speed and accuracy } \\
\text { of response by the nu deux } \\
\text { in the fourth }\end{array}$} & Second & $1 . r v$ & $\because r$ & I.rV & $\because r$ & $\cdot \wedge \leq \varepsilon$ \\
\hline & & Score & 1.0 & .00 & A.rV & .0 & $\cdot 1 \cdot 9$ \\
\hline \multirow[t]{2}{*}{7} & \multirow{2}{*}{$\begin{array}{c}\text { Test of speed and accuracy } \\
\text { of response by the } \\
\text { coupdroit in the seventh }\end{array}$} & Second &.$V$ & $\because \cdot 1$ & $\because V$ & $\because 1$ & $.94 \varepsilon$ \\
\hline & & Score & V.TV & 1.4 & $\mathrm{V.01}$ & .94 & .910 \\
\hline \multirow[t]{2}{*}{8} & \multirow{2}{*}{$\begin{array}{c}\text { Test of speed and accuracy } \\
\text { of response by the } \\
\text { disengage in the seventh }\end{array}$} & Second & 1.10 & .11 & I.t & .17 & $.91 \leq$ \\
\hline & & Score & $V .7 V$ & 1.41 & V.7 & 1.47 & .994 \\
\hline \multirow[t]{2}{*}{9} & \multirow{2}{*}{$\begin{array}{l}\text { Test of speed and accuracy } \\
\text { of response by the nu deux } \\
\text { in the seventh }\end{array}$} & Second & $1 . \mu$ & $\because r$ & I.rv & $\because r$ & ש \\
\hline & & Score & V.Ar & $\because 10$ & V.Vo &.$\vee 7$ & $.97 \leq$ \\
\hline \multirow[t]{2}{*}{10} & \multirow{2}{*}{$\begin{array}{c}\text { Test of speed and accuracy } \\
\text { of response by the } \\
\text { coupdroit in the eighth }\end{array}$} & Second & .7 & $\because 7$ & .09 & $\because 7$ & .910 \\
\hline & & Score & V & $1 . \leqslant 1$ & 7.94 & 1.07 & .997 \\
\hline \multirow[t]{2}{*}{11} & \multirow{2}{*}{$\begin{array}{c}\text { Test of speed and accuracy } \\
\text { of response by the } \\
\text { disengage in the eighth }\end{array}$} & Second & $1.1 \mathrm{~V}$ & $\because 0$ & 1.10 & $\because \varepsilon$ & $\because \wedge 07$ \\
\hline & & Score & 0.0 & $1 . \wedge V$ & $0 . \leqslant r$ & 1.17 & $.99 \leq$ \\
\hline \multirow[t]{2}{*}{12} & \multirow{2}{*}{$\begin{array}{l}\text { Test of speed and accuracy } \\
\text { of response by the nu deux } \\
\text { in the eighth }\end{array}$} & Second & אז. & $\because \varepsilon$ & $1 . r \varepsilon$ & $\because v$ & $.9 Y 7$ \\
\hline & & Score & V.r & 1.41 & $\mathrm{V.1V}$ & 1.18 & $* .907$ \\
\hline
\end{tabular}

$\mathrm{R}$ tabulated value at 0.05 level of significance $=0.707$ 
Through table ( $\varepsilon)$, there is a significant correlation between the mean scores of the two administrations, the first and second, as calculated $\mathrm{R}$ value ranged from 0.809 to 0.996 which is bigger than its tabulated value at 0.05 level, indicating the reliability of the tests under study.

\section{The main study:}

The researcher administered the tests under study in three weeks, The sample included study of fleuret players under 20 years, starting from Saturday the $23^{\text {rd. }}$ April, 2016 to Friday the $13^{\text {th }}$, May, 2016, Where a week was allocated for each of the three clubs to apply (12) test appendix (4), the same conditions and conditions of application to all players in all clubs, and the following test model for explanation and clarification

Test name: the speed and accuracy of direct simple response (by the coupdroit ) in the sixth.

Test purpose: measuring the speed and accuracy of response by the coupdroit hit in the sixth.

Tools used: swordsmanship's playground, 2 legal fencing swords, a legal jacket of a fencing suit which has been divided in the front into 4 sections, then 10 interrelated circles were drawn and numbered from 1 for the external circle to 10 for the internal one. For each of such sections, there is a camera with a filming speed of $1 / 1000 \mathrm{~s}$, a camera stick, a whistle for signaling the game start, a recording form and a laptop with classic media player software for measuring the speed of $1 / 1000 \mathrm{~s}$.

\section{Test description:}

- The examinee and disengage readily stand with no blade--when the disengage listens to the starting whistle, he positively and strongly attacks and stabs in the sixth.

The examinee defends and directly responds at his highest speed possible also in the sixth using the coupdroit skill (direct simple response) while stabbing and recording a touch.

\section{Performance conditions:}

- Specifying the suitable space for the examinee before performing.

The disengage must be positive with a high level performance.

The disengage must not be exhausted to maintain his performance level.

- The examinee's defense must be successful.

- The performance must be at the highest speed possible.

\section{Recording:}

The examinee's speed is calculated approximately to $1 / 1000 \mathrm{~s}$ from the moment of the fly sword's motion of the examinee for defense and 
response to touch the disengage's target fly sword.

The accuracy is calculated for each examinee in scores. The number of the circle touched by the fly sword is recorded and calculated. The accuracy score is 10 interrelated circles and numbered from 1 for the external circle to 10 for the central one.

Number of trials: a player is given one trial.

\section{Statistical calculations:}

The researcher used the following statistical calculations to process the results: Man-Whitney test, Skewness coefficient, kurtosis coefficient and percentiles.

\section{Presenting and discussing results:}

Depending on the outcomes of statistical analysis of research data and making use of references and studies, results were discussed based on the research questions as follows:

Presenting and discussing the results of the first question: "What are the tests that measure the speed and accuracy of simple response skill (by the coupdroit and disengage ) and the complex (by the numerical) in the sixth, fourth, seventh and eighth of fencing under-20-year players?"-following is a model of such tests:
The researcher sees that test design means the set of sequential steps to attain a tool that measures a characteristic, skill or specified function

characterized by such scientific conditions as validity, reliability and objectivity. Test validity is attained when it measures what it intends to measure; a reliable test gives the same results of its readministrations.

Test objectivity, on the other hand, means that test results are free from the examiner's subjective judgment. Such subjectivity is affected by two factors: the examiner's understanding of test goals and instructions and the evaluation method, thus meaning that the examiner's score is not affected by whoever evaluates, according to Mohamed Sobhi (1990)and Liyla Alsayed $(Y \cdots 0) .(8: 171)(V \leq: \vee)$.

The researcher indicates that recording was by accurate devices and programs for measuring performance time and assigning results for measuring performance accuracy related to the circle's number that the fly sword touches. Thus, tests are considered highly objective, non-interpretable and away from subjective judgment as the test shows (appendix 4).

The researcher also thinks that a good research is that 
whose situations are similar to those of competition according to Mohamed Sobhi :9)(1990) ( $\mathrm{V}$ ). Consequently, one of the performance conditions is that a strong positive disengage to create a competitive atmosphere so that the player shall have the desire to perform at the highest speed possible for recording a touch.

Presenting and discussing the results of the second question: "Is it possible to set test-appropriate standard levels that measure the speed and accuracy of simple response skill (using the coupdroit and disengage) and the complex (using the numerical) in the sixth, fourth, seventh and eighth for fencing under-20year players?

To answer such a question, mean, average, standard deviation, Skewness and kurtosis coefficients, the highest and lowest values and percentiles were used. Results of table $(0)$ illustrate that:

\section{Table ( 5)}

mean, average standard deviation, Skewness and kurtosis coefficients, the highest and lowest value sfor speed and accuracy of response in the sixth, fourth, seventh and eighth $(n=25)$

\begin{tabular}{|c|c|c|c|c|c|c|c|}
\hline \multirow{2}{*}{\multicolumn{2}{|c|}{ Statistics }} & \multicolumn{2}{|c|}{$\begin{array}{c}\text { Test of speed and } \\
\text { accuracy of response } \\
\text { by the coupdroit in } \\
\text { the sixth }\end{array}$} & \multicolumn{2}{|c|}{$\begin{array}{c}\text { Test of speed and } \\
\text { accuracy of response } \\
\text { by the disengage in } \\
\text { the sixth }\end{array}$} & \multicolumn{2}{|c|}{$\begin{array}{l}\text { Test of speed and } \\
\text { accuracy of } \\
\text { response by the nu } \\
\text { deux in the sixth }\end{array}$} \\
\hline & & $\overline{\text { Second }}$ & Score & Second & Score & $\overline{\text { Second }}$ & Score \\
\hline & mean & .5836 & 8.3500 & 1.1132 & 6.3000 & 1.3036 & 6.8000 \\
\hline & average & .5790 & 8.5000 & 1.0900 & 6.0000 & 1.3010 & 7.0000 \\
\hline \multicolumn{2}{|c|}{ Standard deviation } & .03305 & 1.18210 & .06411 & 1.17429 & .03832 & 1.28145 \\
\hline \multicolumn{2}{|c|}{ Skewness coefficient } & $.265-$ & .080 & .865 & $.438-$ & .088 & .080 \\
\hline \multicolumn{2}{|c|}{ Kurtosis coefficient } & $.590-$ & $1.541-$ & $.432-$ & $.187-$ & $1.195-$ & $.893-$ \\
\hline \multicolumn{2}{|c|}{ lowest values } & .52 & 6.00 & 1.04 & 4.00 & 1.25 & 5.00 \\
\hline \multicolumn{2}{|c|}{ highest values } & .64 & 10.00 & 1.24 & 8.00 & 1.36 & 9.00 \\
\hline \multirow{3}{*}{ 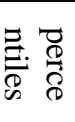 } & ro percentiles & .6088 & 7.0000 & 1.1800 & 5.0000 & 1.3400 & 6.0000 \\
\hline & $0 \cdot$ percentiles & .5790 & 8.5000 & 1.0900 & 6.0000 & 1.3010 & 7.0000 \\
\hline & Vo percentiles & .5575 & 9.0000 & 1.0625 & 7.0000 & 1.2700 & 8.0000 \\
\hline \multicolumn{2}{|c|}{ Measurement unit } & Second & Score & Second & Score & Second & Score \\
\hline \multicolumn{2}{|r|}{ mean } & .6074 & 6.6000 & 1.1636 & 6.2400 & 1.3134 & 7.3200 \\
\hline \multicolumn{2}{|r|}{ average } & .6100 & 7.0000 & 1.2010 & 6.0000 & 1.3090 & 7.0000 \\
\hline \multicolumn{2}{|c|}{ Standard deviation } & .05709 & 1.47196 & .05254 & 1.71464 & .03421 & 1.18040 \\
\hline \multicolumn{2}{|c|}{ Skewness coefficient } & $-.089-$ & $-.170-$ & $-.846-$ & $-.244-$ & 1.256 & $-.356-$ \\
\hline \multicolumn{2}{|c|}{ Kurtosis coefficient } & $-.496-$ & $-.972-$ & $-.863-$ & $-.656-$ & 1.005 & $-.555-$ \\
\hline \multicolumn{2}{|c|}{ lowest values } & .51 & 5.00 & 1.06 & 3.00 & 1.26 & 5.00 \\
\hline \multicolumn{2}{|c|}{ highest values } & .70 & 9.00 & 1.21 & 9.00 & 1.39 & 9.00 \\
\hline
\end{tabular}


Follow Table ( 5)

mean, average standard deviation, Skewness and kurtosis coefficients, the highest and lowest value sfor speed and accuracy of response in the sixth, fourth, seventh and eighth $(n=25)$

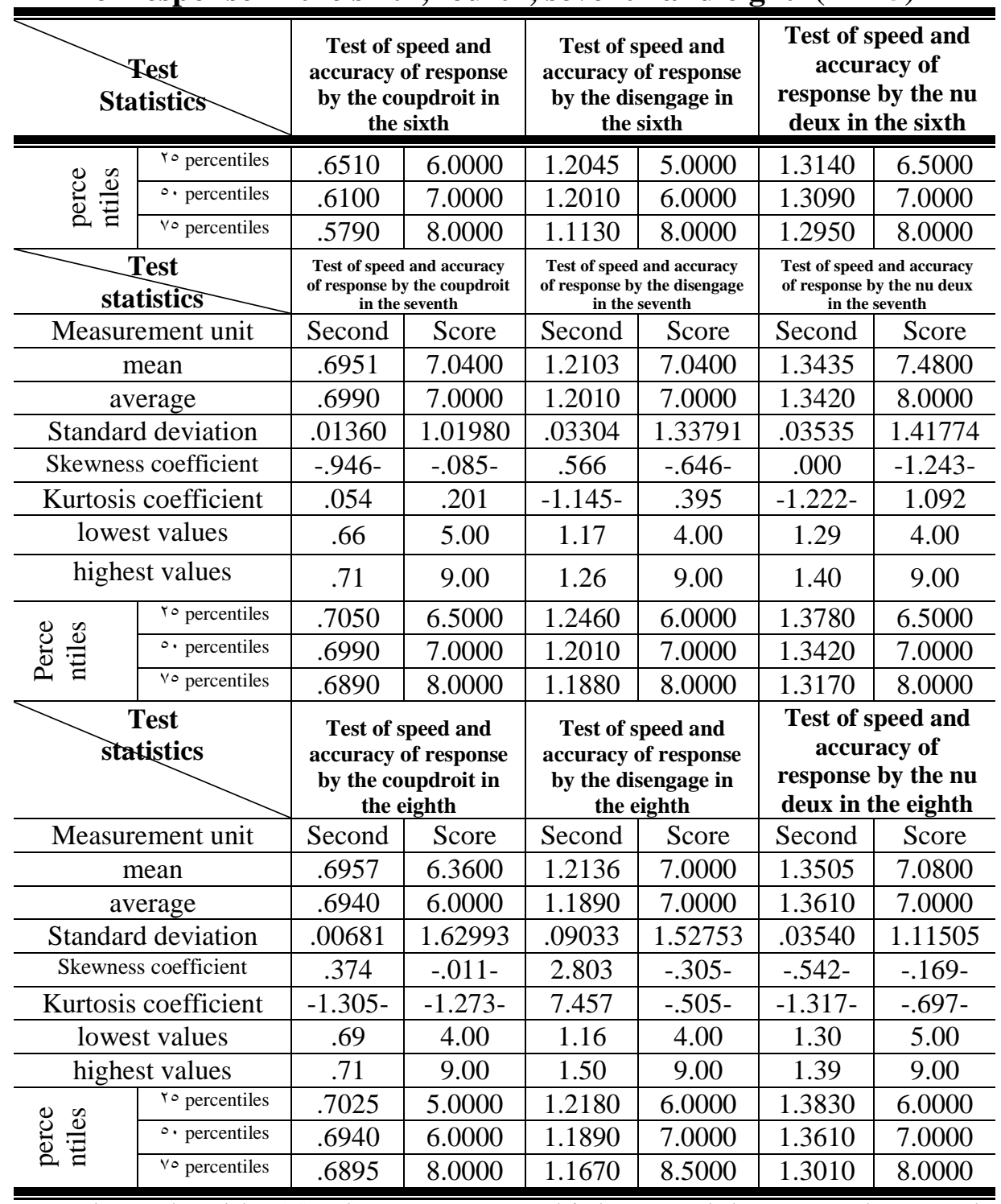

Through table (5), there are the values of means, standard deviation, Skewness and kurtosis coefficients, the highest and lowest values and percentiles of response speed and accuracy (by the coupdroit disengage and numerical in

\section{Assiut Journal For Sport Science Arts}


the sixth, fourth, seventh and eighth-since the mean values were (5836، 6074، 1.1132، ، ، 1.3505)/s successively. Average values were as follows (8.3500،6.6000،6.300،6.4000،6 $.8000 \times 7.3200 \times 7.0400 \times 6.360067$. 0400 ، 7, 0000 ،7.4800، 7.0800 successively for fencing under20-year )

Since Skewness values ranged from $\left(r_{ \pm}\right)$in all skills, this indicates the sample homogeneity 0and the normal distribution of the sample's individuals' scores, thus standard levels could be developed. Based on the results of the lowest and highest values and the percentiles 25 , 50, 75, 6 standard levels were set as table 6 illustrates.

The researcher explains why shy used the lowest and highest values and the percentiles 25 , 50,75 to set standard levels as standards are one of the objective means applicable to individuals' performance assessment. Tests raw scores

\section{Table (6) \\ Standard levels for test of speed and accuracy of simple response (by the coupdroit and disengage) and the complex (by the nu deux)}

\begin{tabular}{|c|c|c|c|c|c|c|c|c|}
\hline $\begin{array}{l}\mathbf{N} \\
\mathbf{o}\end{array}$ & $\begin{array}{c}\text { Standard level } \\
\text { Test }\end{array}$ & こ & Excellent & $\begin{array}{l}\text { Very } \\
\text { good }\end{array}$ & Good & Fair & Weak & $\begin{array}{l}\text { Very } \\
\text { weak }\end{array}$ \\
\hline \multirow{2}{*}{1} & \multirow{2}{*}{$\begin{array}{l}\text { Test of speed and } \\
\text { accuracy of response } \\
\text { by the coupdroit in } \\
\text { the sixth }\end{array}$} & Second & $\begin{array}{c}\text { down : .5200 } \\
\text { ward }\end{array}$ & $\begin{array}{l}.5201: . \\
5570\end{array}$ & $\begin{array}{c}.5571: .5 \\
590\end{array}$ & $\begin{array}{c}.6088: .5 \\
591\end{array}$ & $\begin{array}{c}.6400: .6 \\
089\end{array}$ & $\begin{array}{c}\text { up } \begin{array}{c}: .6401 \\
\text { ward }\end{array}\end{array}$ \\
\hline & & Score & $\begin{array}{c}: 1 \cdot \\
\text { upward }\end{array}$ & 9.99 .9 & $\begin{array}{l}-1.0 \ldots \\
1.99\end{array}$ & $8.499-7$ & 7.99 .7 & $\begin{array}{c}: 5.99 \\
\text { downward }\end{array}$ \\
\hline \multirow[b]{2}{*}{2} & \multirow{2}{*}{$\begin{array}{l}\text { Test of speed } \\
\text { and accuracy of } \\
\text { response by the } \\
\text { disengage in the } \\
\text { sixth }\end{array}$} & Second & $\begin{array}{c}1.0400 \\
\text { downward } \\
\end{array}$ & $\begin{array}{l}: 1.0625 \\
1.0401 \\
\end{array}$ & $\begin{array}{l}: 1.0900 \\
1.0626 \\
\end{array}$ & $\begin{array}{l}: 1.1800 \\
1.0901 \\
\end{array}$ & $\begin{array}{l}: 1.2400 \\
1.1801\end{array}$ & $\begin{array}{l}: 1.2401 \\
\text { upward }\end{array}$ \\
\hline & & Score & $\begin{array}{c}:^{\wedge} \\
\text { upward }\end{array}$ & V. $99: \vee$ & $7.99: 7$ & $0.99: 0$ & $\leqslant .99: \leqslant$ & $\begin{array}{c}: 3.99 \\
\text { downward }\end{array}$ \\
\hline
\end{tabular}

have no any indication or significance unless we refer back to a standard clarifying the meaning of such scores, for instance the individual's position compared to his group, above or over average, how far is he from that group's average and what is his position compared to his peers?

In this concern, Mohamed Sobhi (2004) agrees that percentile standards are one of the important means used for the interpretation of raw scores for many tests. Percentile standards are one of the most used methods for describing the relative cases of standardization samples' performance in different tests, in the form of percentile ranks (grades), since they are suitable for interpreting scores as for the player and trainer. Such standards often contain values that represent performance scores since they provide sufficient opportunities for interpreting anybody's scores when comparing his level to his peers'. (35:10) 
Follow Table (6)

Standard levels for test of speed and accuracy of simple response (by the coupdroit and disengage) and the complex (by the nu deux)

\begin{tabular}{|c|c|c|c|c|c|c|c|c|}
\hline $\begin{array}{l}\mathbf{N} \\
\mathbf{o}\end{array}$ & $\begin{array}{c}\text { Standard level } \\
\text { Test }\end{array}$ & 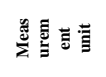 & Excellent & $\begin{array}{l}\text { Very } \\
\text { good }\end{array}$ & Good & Fair & Weak & $\begin{array}{l}\text { Very } \\
\text { weak }\end{array}$ \\
\hline \multirow{2}{*}{3} & \multirow{2}{*}{$\begin{array}{c}\text { Test of speed and } \\
\text { accuracy of response } \\
\text { by the nu deux in the } \\
\text { sixth }\end{array}$} & Second & $\begin{array}{c}: 1.2500 \\
\text { downward }\end{array}$ & $\begin{array}{c}: 1.2501 \\
1.2700 \\
\end{array}$ & $\begin{array}{c}: 1.2701 \\
1.3010 \\
\end{array}$ & $\begin{array}{c}: 1.3400 \\
1.3011 \\
\end{array}$ & $\begin{array}{l}: 1.3401 \\
1.3600 \\
\end{array}$ & $\begin{array}{l}: 1.3601 \\
\text { upward }\end{array}$ \\
\hline & & Score & $\begin{array}{c}:^{9} \\
\text { upward }\end{array}$ & ^.99:^ & $\vee .99: \vee$ & $7.99: 7$ & $0.99: 0$ & $\begin{array}{c}: \leqslant .99 \\
\text { downward }\end{array}$ \\
\hline \multirow{2}{*}{4} & \multirow{2}{*}{$\begin{array}{l}\text { Test of speed and } \\
\text { accuracy of response } \\
\text { by the coupdroit in } \\
\text { the fourth }\end{array}$} & Second & $\begin{array}{c}: .5100 \\
\text { downward }\end{array}$ & $\begin{array}{l}. .5790 \\
.5100 \\
\end{array}$ & $\begin{array}{l}. .6100 \\
.5791 \\
\end{array}$ & $\begin{array}{l}. .6510 \\
.6101 \\
\end{array}$ & $\begin{array}{l}. .7000 \\
.6511 \\
\end{array}$ & $\begin{array}{c}: .7001 \\
\text { upward } \\
\end{array}$ \\
\hline & & Score & $\begin{array}{c}: 9 \\
\text { upward }\end{array}$ & $\wedge .99: \wedge$ & $\vee .99: \vee$ & $7.99: 7$ & $0: 0.99$ & $\begin{array}{c}: 乏 .99 \\
\text { downward }\end{array}$ \\
\hline \multirow{2}{*}{5} & \multirow{2}{*}{$\begin{array}{l}\text { Test of speed and } \\
\text { accuracy of response } \\
\text { by the disengage in } \\
\text { the fourth }\end{array}$} & Second & $\begin{array}{c}: 1.0600 \\
\text { downward }\end{array}$ & $\begin{array}{l}: 1.1130 \\
1.0601\end{array}$ & $\begin{array}{l}: 1.2010 \\
1.1131\end{array}$ & $\begin{array}{l}: 1.2045 \\
1.2011\end{array}$ & $\begin{array}{l}: 1.2100 \\
1.2046\end{array}$ & $\begin{array}{l}\text { : } 1.2101 \\
\text { upward }\end{array}$ \\
\hline & & Score & $\begin{array}{c}:^{9} \\
\text { upward } \\
\end{array}$ & $\wedge .99: \wedge$ & $\vee .99: 7$ & $0.99: 0$ & r & $\begin{array}{c}: \curlyvee .99 \\
\text { downward }\end{array}$ \\
\hline \multirow{2}{*}{6} & \multirow{2}{*}{$\begin{array}{l}\text { Test of speed and } \\
\text { accuracy of response } \\
\text { by the nu deux in the } \\
\text { fourth }\end{array}$} & Second & $\begin{array}{c}: 1.2600 \\
\text { downward } \\
\end{array}$ & $\begin{array}{l}1.2601: \\
1.2950\end{array}$ & $\begin{array}{l}: 1.3420 \\
1.2951 \\
\end{array}$ & $\begin{array}{l}: 1.3780 \\
1.3421 \\
\end{array}$ & 1.3900 & $\begin{array}{l}1.3901 \\
\text { upward } \\
\end{array}$ \\
\hline & & Score & $\begin{array}{c}: 9 \\
\text { upward } \\
\end{array}$ & $\wedge .99: \wedge$ & $\vee .99: \vee$ & $\begin{array}{l}7.0 \cdots \\
7.99 \\
\end{array}$ & $7 . \leqslant 99: 0$ & $\begin{array}{c}: \leq .99 \\
\text { downward }\end{array}$ \\
\hline \multirow[t]{2}{*}{7} & \multirow{2}{*}{$\begin{array}{l}\text { Test of speed and } \\
\text { accuracy of response } \\
\text { by the coupdroit in } \\
\text { the seventh }\end{array}$} & Second & $\begin{array}{c}: .6600 \\
\text { downward }\end{array}$ & $\begin{array}{l}. .6890 \\
.6601\end{array}$ & $\begin{array}{l}.6990 \\
.6891\end{array}$ & $\begin{array}{l}. .7050 \\
.6991\end{array}$ & $\begin{array}{l}. .7100 \\
.7051\end{array}$ & $\begin{array}{l}: .7101 \\
\text { upward }\end{array}$ \\
\hline & & Score & $\begin{array}{c}:^{9} \\
\text { upward }\end{array}$ & $\wedge .99: \wedge$ & $\vee .99: \vee$ & $\begin{array}{l}7.0 \% \\
7.99\end{array}$ & $7 . \leqslant 99: 0$ & $\begin{array}{c}: 乏 .99 \\
\text { downward }\end{array}$ \\
\hline \multirow{2}{*}{8} & \multirow{2}{*}{$\begin{array}{l}\text { Test of speed and } \\
\text { accuracy of response } \\
\text { by the disengage in } \\
\text { the seventh }\end{array}$} & Second & $\begin{array}{c}: 1.1700 \\
\text { downward } \\
\end{array}$ & $\begin{array}{l}1.1701: \\
1.1880\end{array}$ & $\begin{array}{l}: 1.2010 \\
1.1881 \\
\end{array}$ & $\begin{array}{l}: 1.2460 \\
1.2011 \\
\end{array}$ & $: 1.2600$ & $\begin{array}{l}: 1.2601 \\
\text { upward }\end{array}$ \\
\hline & & Score & $\begin{array}{c}:^{9} \\
\text { upward }\end{array}$ & $1.99: \wedge$ & $\vee .99: \vee$ & $7.99: 7$ & $0.99: \varepsilon$ & $\begin{array}{c}: \Upsilon .99 \\
\text { downward }\end{array}$ \\
\hline \multirow{2}{*}{9} & \multirow{2}{*}{$\begin{array}{c}\text { Test of speed and } \\
\text { accuracy of response } \\
\text { by the nu deux in the } \\
\text { seventh }\end{array}$} & Second & $\begin{array}{c}: 1.2900 \\
\text { downward }\end{array}$ & $\begin{array}{l}: 1.3170 \\
1.2901 \\
\end{array}$ & $\begin{array}{l}: 1.3420 \\
1.3171 \\
\end{array}$ & $\begin{array}{l}: 1.3780 \\
1.3421 \\
\end{array}$ & $\begin{array}{l}: 1.3781 \\
1.4000 \\
\end{array}$ & $\begin{array}{l}1.4001 \\
\text { upward }\end{array}$ \\
\hline & & Score & $\begin{array}{c}: 9 \\
\text { upward }\end{array}$ & $1.99: 1$ & $\vee .99: \vee$ & $\begin{array}{l}: 7.0 \cdots \\
7.99\end{array}$ & $7 . \leqslant 99: \leqslant$ & $\begin{array}{c}: r .99 \\
\text { downward }\end{array}$ \\
\hline \multirow{2}{*}{$\begin{array}{l}1 \\
0\end{array}$} & \multirow{2}{*}{$\begin{array}{l}\text { Test of speed and } \\
\text { accuracy of response } \\
\text { by the coupdroit in } \\
\text { the eighth }\end{array}$} & Second & $\begin{array}{c}: .6900 \\
\text { downward } \\
\end{array}$ & $\begin{array}{l}. .6895 \\
.6901 \\
\end{array}$ & $\begin{array}{l}. .6940 \\
.6896 \\
\end{array}$ & $\begin{array}{l}. .7025 \\
.6941 \\
\end{array}$ & $\begin{array}{l}. .7100 \\
.7026 \\
\end{array}$ & $\begin{array}{c}.7101 \\
\text { upward } \\
\end{array}$ \\
\hline & & Score & $\begin{array}{c}: 9 \\
\text { upward }\end{array}$ & $\wedge .99: \wedge$ & $\vee .99: 7$ & $7.99: 0$ & $0.99: \leq$ & $\begin{array}{c}: r .99 \\
\text { downward }\end{array}$ \\
\hline \multirow{2}{*}{$\begin{array}{l}1 \\
1\end{array}$} & \multirow{2}{*}{$\begin{array}{l}\text { Test of speed and } \\
\text { accuracy of response } \\
\text { by the disengage in } \\
\text { the eighth }\end{array}$} & Second & $\begin{array}{c}: 1.1600 \\
\text { downward }\end{array}$ & $\begin{array}{l}: 1.1670 \\
1.1601\end{array}$ & $\begin{array}{l}: 1.1890 \\
1.1671 \\
\end{array}$ & $\begin{array}{l}: 1.2180 \\
1.1891 \\
\end{array}$ & $\begin{array}{l}: 1.5000 \\
1.2181\end{array}$ & $\begin{array}{l}\text { :1.5001 } \\
\text { upward }\end{array}$ \\
\hline & & Score & $\begin{array}{c}:^{9} \\
\text { upward }\end{array}$ & $\begin{array}{l}: \wedge .0 \ldots \\
\wedge .99\end{array}$ & ^. $\leqslant q: \vee$ & $7.99: 7$ & $0.99: \varepsilon$ & $\begin{array}{c}:\ulcorner .99 \\
\text { downward }\end{array}$ \\
\hline \multirow{2}{*}{$\begin{array}{l}1 \\
2\end{array}$} & \multirow{2}{*}{$\begin{array}{c}\text { Test of speed and } \\
\text { accuracy of response } \\
\text { by the nu deux in the } \\
\text { eighth }\end{array}$} & Second & $\begin{array}{c}: 1.3000 \\
\text { downward }\end{array}$ & $\begin{array}{l}: 1.3010 \\
1.3001 \\
\end{array}$ & $\begin{array}{l}: 1.3610 \\
1.3011 \\
\end{array}$ & $\begin{array}{l}: 1.3830 \\
1.3611 \\
\end{array}$ & $\begin{array}{l}: 1.3900 \\
1.3831 \\
\end{array}$ & $\begin{array}{l}1.3901 \\
\text { upward }\end{array}$ \\
\hline & & Score & :9 upward & $1.99: 1$ & $\vee . १ १: \vee$ & $7.99: 7$ & $0: 0.99$ & $\begin{array}{c}: \leqslant .99 \\
\text { downward }\end{array}$ \\
\hline
\end{tabular}

Table (6) shows the raw scores correspondiregged standaredevethaforefdece stitils of simple respor trained individuals, so they are set after training and practice for the purpose of achievement or improving the characteristic to

highest level of such a characteristic. (62:4)

Discussing the third question: Is there a correlation between 
speed and accuracy in simple response skill (by coupdroit and disengage) and the complex (by numerical) in the sixth, fourth, seventh and eighth for under-20year fleuret players ?
To answer this question, the average, standard deviation and Pearson correlation were calculated as Table (7) shows:

Table (7)

The average, standard deviation and Pearson correlation between the time and accuracy of fleuret players ' performance in the tests under study $(\mathrm{N}=25)$

\begin{tabular}{|c|c|c|c|c|c|}
\hline No & Variables & Measurement unit & Average & Standard deviation & R Value \\
\hline \multirow[t]{2}{*}{1} & \multirow{2}{*}{$\begin{array}{c}\text { Test of speed and accuracy } \\
\text { of response by the } \\
\text { coupdroit in the sixth }\end{array}$} & Second & $.0 \wedge \wedge r$ & . & \multirow[b]{2}{*}{ *.077. } \\
\hline & & Score & מזה • & VIו & \\
\hline \multirow[t]{2}{*}{$r$} & \multirow{2}{*}{$\begin{array}{c}\text { Test of speed and accuracy } \\
\text { of response by the } \\
\text { disengage in the sixth }\end{array}$} & Second & 1.1 .77 & $\because .71 \cdot 1$ & \multirow{2}{*}{$* * . \wedge r \cdot-$} \\
\hline & & Score & 7.7778 & $1 . r v .79$ & \\
\hline \multirow[t]{2}{*}{$r$} & \multirow{2}{*}{$\begin{array}{l}\text { Test of speed and } \\
\text { accuracy of response by } \\
\text { the nu deux in the sixth }\end{array}$} & Second & $1 . r .11$ & . & \multirow{2}{*}{$* *, . \vee \leq}$. \\
\hline & & Score & 7.10 & $1 . r 10 \leqslant r$ & \\
\hline \multirow[t]{2}{*}{$\varepsilon$} & \multirow{2}{*}{$\begin{array}{c}\text { Test of speed and accuracy } \\
\text { of response by the } \\
\text { coupdroit in the fourth }\end{array}$} & Second & $.79 \% \wedge$ & $\because \cdot 1 \leq \leq \mu$ & \multirow{2}{*}{$* * .7 \wedge 0_{-}$} \\
\hline & & Score & שMA. & 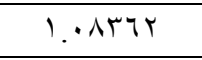 & \\
\hline \multirow[t]{2}{*}{0} & \multirow{2}{*}{$\begin{array}{c}\text { Test of speed and accuracy } \\
\text { of response by the } \\
\text { disengage in the fourth }\end{array}$} & Second & $1 . r .91$ & $\because .01 \mathrm{~V}$ & \multirow{2}{*}{$* * . \vee \vee q_{-}$} \\
\hline & & Score & $7.917 V$ & VעrוI. & \\
\hline \multirow[t]{2}{*}{7} & \multirow{2}{*}{$\begin{array}{l}\text { Test of speed and } \\
\text { accuracy of response by } \\
\text { the nu deux in the fourth }\end{array}$} & Second & $1 . \Gamma \leq \vee \wedge$ & . rtor & \multirow{2}{*}{$* * . \wedge \circ \tau_{-}$} \\
\hline & & Score & $V .0$ & 1.0 .107 & \\
\hline \multirow[t]{2}{*}{$\mathrm{V}$} & \multirow{2}{*}{$\begin{array}{c}\text { Test of speed and accuracy } \\
\text { of response by the } \\
\text { coupdroit in the seventh }\end{array}$} & Second & .7901 & $\because \cdot v_{1}$ & \multirow{2}{*}{$* * . \wedge 10_{-}$} \\
\hline & & Score & $7.517 V$ & $1.7 \vee 7 \leq 9$ & \\
\hline \multirow[t]{2}{*}{$\Lambda$} & \multirow{2}{*}{$\begin{array}{l}\text { Test of speed and accuracy } \\
\text { of response by the } \\
\text { disengage in the seventh }\end{array}$} & Second & 1.117 & $\because 9 r \leq 1$ & \multirow{2}{*}{$* * .07 \Lambda_{-}$} \\
\hline & & Score & V & $1.090 \leqslant 0$ & \\
\hline \multirow[t]{2}{*}{9} & \multirow{2}{*}{$\begin{array}{l}\text { Test of speed and accuracy of } \\
\text { response by the nu deux in the } \\
\text { seventh }\end{array}$} & Second & 1. 1. & . rorv & \multirow{2}{*}{$* * ., V \leq 0$} \\
\hline & & Score & V.AMT & $1.17 \leq 0$ & \\
\hline \multirow[t]{2}{*}{1.} & \multirow{2}{*}{$\begin{array}{l}\text { Test of speed and accuracy of } \\
\text { response by the coupdroit in } \\
\text { the eighth }\end{array}$} & Second & $.7 \cdot \leq r$ & $\because$ OVYO & \multirow{2}{*}{$* * . \wedge \leq \cdot-$} \\
\hline & & Score & $7.777 \mathrm{~V}$ & $1 . \leq 9 V \leq V$ & \\
\hline \multirow[t]{2}{*}{11} & \multirow{2}{*}{$\begin{array}{l}\text { Test of speed and accuracy of } \\
\text { response by the disengage in } \\
\text { the eighth }\end{array}$} & Second & $1.17 r$ & $\because 0 \leq Y V$ & $* * .09$. \\
\hline & & Score & 7.1778 & 1. $v \leqslant 9 \leqslant 7$ & $* * . \wedge \leq$. \\
\hline \multirow[t]{2}{*}{ Ir } & \multirow{2}{*}{$\begin{array}{l}\text { Test of speed and accuracy of } \\
\text { response by the nu deux in the } \\
\text { eighth }\end{array}$} & Second & ع & $\because$ rovr & $* *, \quad y<0$ \\
\hline & & Score & 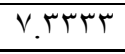 & $1.4+91$ & \\
\hline
\end{tabular}

* Significant at 0.05 level of significance $* *$ Significant at 0.01 level of significance 
The table illustrates the existence of a significant negative (contrary) correlation between fleuret players ' averages in the time and accuracy of performance in the physical skill-based tests of the sample under study as $\mathrm{R}$ value ranged from $\cdot .077$ to $\cdot .107$. The researcher analyzes that since the less the time of performance, the more its speed and accuracy as the statistical calculations measure speed of performance and time measured by second. Thus, the less the performance time, the more its accuracy for fleuret players in the physical skillbased tests of the sample under study. In the light of that, the researcher found a significant negative (contrary) correlation between the speed and accuracy during simple skill performance (by the coupdroit and disengage ) and the complex (using the numerical) in the sixth, fourth, seventh and eighth for under-20-year fleuret players .

This result conforms to the study of Dhurgam (2002) (6:77) that there is a contrary correlation between speed of movement and accuracy of stabbing as it agrees on such a correlation between speed and accuracy, generally. Alternatively, it disagrees with this study in the type of skill and thus the test and sample.

Conclusions:

1- 2 tests of the speed and accuracy of simple response skill (by the coupdroit and disengage) and the complex (by the numerical) in the sixth, fourth, seventh and eighth for under-20-year fleuret players were standardized.

2- he tests are characterized by validity, reliability and objectivity when applied on similar samples of under-20-year fleuret players .

3 - he tests have a discriminative ability among under-20-year fleuret players' individual differences.

4- x standard levels have been attained (namely, excellent, very good, good, fair, weak and very weak. S

5 - here is a contrary correlation between the speed and accuracy of performance during testing under-20-year fleuret players.

\section{Recommendations:}

1- Designing a similar study of standardizing and setting standard levels for tests that are imitating the movement track of the actual performance during competition as for attack, defense and counter response skills of swordsmanship in particular and other individual or team sports in general.

2- Administration of tests under study and its standard levels for the benefit of training on swordsmanship.

\section{The list of references:}

\section{First: References in Arabic:} 1. Ibrahim Nabil Abdul Aziz: the technical foundations for fencing, i2, Book Publishing Center, Cairo (2005). 
2- Osama Abdul Rahman: basic principles in the duel, printing house, Alexandria (2003m).

3- Osama Abdul Rahman, Sameh Mohamed Magda: and science fencing, University of printing Publishing, Mansoura (2009m).

\section{Iman Hussein al-Tai:} measurement and testing in sports education, publishing house, Iraq (2005).

5. Hussein pilgrims and Ramzi el tanbolee: Fencing science and art, printing and publishing, the conquest of Alexandria (2No. 98/007).

6. Door Ghanem "accuracy of the appeal and its relationship to respond to the mobility and balance to the EPEE players", Faculty of Education Sports, University of Mosul (2002m)

7. Liyla el Sayed. Farahat: measurement and testing in education, sports book center publishing, Cairo (2005).

8- Mohamed

Sobhi

Hassanein: measurement and evaluation in physical education and sports, i3, the Arab Thought oundation, Cairo (1995).
9- Mohamed

Sobhi

Hassanein: measurement and evaluation in the sports education1, the Arab Thought House, Cairo (2001m).

10. Mohamed

Sobhi

Hassanein: measurement and evaluation in the sports education, part II, i5, the Arab Thought Foundation, Cairo (2004m).

\section{Mohammad Mahmoud}

Abdul Rahim: "a proposed training program using skill performances of the vehicle and its impact on the accuracy of the speed and effectiveness of the performance of the skilled players of fencing", Master Thesis, Faculty of Physical Education, University of Assiut (2014 m).

Secondly: the sites of the international information network (Internet):

12. http://www.iraqacad.org/ Lib/ Eman1.htm

13. http://stapsbouira.riadah. org/t-topic

14.http://www.badnia.net/ badnia /archive/index.php/t.html

15. https://www.sport.ta4a.us /fitness/1423-speed.html

16. http://tuneps.net/blog/ altoazn-altoafk-aldk 